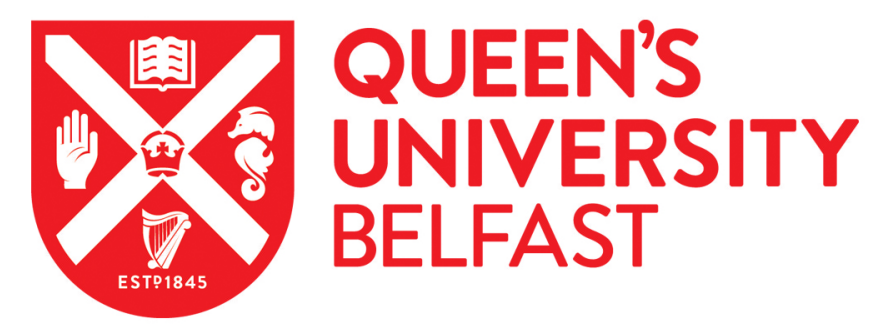

\title{
Children's understanding of ethnic group symbols: Piloting an instrument in the Republic of North Macedonia
}

Tomovska Misoska, A., Taylor, L., Dautel, J., \& Rylander, R. (2020). Children's understanding of ethnic group symbols: Piloting an instrument in the Republic of North Macedonia. Peace and Conflict: Journal of Peace Psychology , 26(1), 82-87. https://doi.org/10.1037/pac0000424

Published in:

Peace and Conflict: Journal of Peace Psychology

Document Version:

Peer reviewed version

Queen's University Belfast - Research Portal:

Link to publication record in Queen's University Belfast Research Portal

Publisher rights

Copyright 2019 American Psychological Association. This work is made available online in accordance with the publisher's policies. Please refer to any applicable terms of use of the publisher.

\section{General rights}

Copyright for the publications made accessible via the Queen's University Belfast Research Portal is retained by the author(s) and / or other copyright owners and it is a condition of accessing these publications that users recognise and abide by the legal requirements associated with these rights.

Take down policy

The Research Portal is Queen's institutional repository that provides access to Queen's research output. Every effort has been made to ensure that content in the Research Portal does not infringe any person's rights, or applicable UK laws. If you discover content in the Research Portal that you believe breaches copyright or violates any law, please contact openaccess@qub.ac.uk. 
RE: CHILDREN AND INTERETHNIC SYMBOLS

Children's understanding of ethnic group symbols: Piloting an instrument in the Republic of North Macedonia

Ana Tomovska Misoska, University American College Skopje, tomovska@uacs.edu.mk

Laura K. Taylor, University College Dublin / Queen's University Belfast, laura.taylor@ucd.ie Jocelyn Dautel, Queen's University Belfast, Jocelyn.Dautel@qub.ac.uk

Risa Rylander, Queen's University Belfast, Risa.Rylander@qub.ac.uk

Correspondence should be addressed to Laura K. Taylor, University College Dublin, laura.taylor@ucd.ie

Acknowledgements: We would like to thank the many schools, parents, and children who participated in this research. The research was carried out as part of the Helping Kids! lab (helpingkidsqubblog.wordpress.com), with financial support from the School of Psychology Research Incentivisation Scheme (RIS) and the Department for the Economy (DfE) - Global Challenge Research Fund (GCRF) Award [DFEGCRF17-18/Taylor] and continuing support from GCRF-GIAA18-19/Taylor and British Psychological Society, Social Psychology Section, Pump-priming and Dissemination Fund Application. There are no conflicts of interest in the preparation or publication of this paper. Research materials can be accessed by contacting Laura K. Taylor. 


\begin{abstract}
Assessing children's awareness of ethnic identity and group boundaries is important in conflictaffected societies. For example, in the Republic of North Macedonia (RNM), tense interethnic relations remain and can be seen in the largely separate living patterns, particularly in schools. This brief report analyses data from 194 children (57.7\% female, $42.3 \%$ male; $45.9 \%$ Macedonian, 54.1\% Albanian) in primary school. A series of one sample t-tests, with Bonferroni correction, demonstrate the viability of a new quantitative tool for measuring children's awareness of symbols relevant to interethnic relations in RNM. The findings indicate that primary school aged children are able to sort both ingroup and outgroup symbols with the hypothesized ethnic group. Moreover, ethnic awareness is present among the earliest school grades and increases with age. This approach may be used in future research and adapted in other conflict-affected settings to better understand the foundations of children's interethnic attitudes and behaviors.
\end{abstract}

Keywords: children; intergroup conflict; interethnic symbols; Republic of North Macedonia; ethnic awareness 


\section{Children's understanding of ethnic group symbols: Piloting an instrument in the Republic of North Macedonia}

Children's ethnic identity, prejudice, and stereotypes are important for understanding intergroup relations. For example, children are aware of group differences early on and tend to prefer their own group (Nesdale, Durkin, Maass, \& Griffiths, 2004). Ethnic awareness is the first phase of Social Identity Development Theory (SIDT; (Nesdale et al., 2004). Yet, little is known about the development of ethnic awareness in contexts where there are no phenotypical differences between groups. In these settings, groups commonly turn to symbols and other visual markers to distinguish themselves, and their territory, from the 'other' (Brewer, 1992). Therefore, uncovering the symbols that children recognize as markers of group identification is important for assessing ethnic awareness.

In settings of intergroup conflict, this importance is heightened as children's awareness of ethnic symbols may have implications for their physical safety and psychological well-being (Cummings, Merrilees, Taylor, \& Mondi, 2017). Past research in Israel, for example, found that children can identify ingroup symbols even before they are aware of the symbols' meaning; moreover, identification increases with age as an understanding of the meaning emerges (Bar-Tal, Diamond, \& Nasie, 2017). Yet, there are differences in the development of ethnic awareness among minority and majority children (Teichman, 2016) and across different settings (Ajdukovic $\&$ Corkalo Biruski, 2008). Therefore, understanding the awareness of group symbols in relation to both age and minority/majority status is critical.

\section{Republic of North Macedonia}

The current study investigates ethnic awareness among children in the Republic of North Macedonia (RNM). The country is inhabited by different ethnicities, with the majority being ethnic 
Macedonians (64\%) and the largest minority group being ethnic Albanians (25\%). The distribution of the population is uneven; the majority of Albanians live in the West/Northwest, in some parts comprising more than $90 \%$ of the population, whereas in some Eastern parts there are no Albanians. The two groups tend to belong to different religions (Macedonians are mostly Orthodox Christians, Albanians are majority Muslim) and speak different languages. The media within the country is split along linguistic lines, and many cultural, sport, and other aspects of everyday life also differ based on ethnic group. Relations between the two groups are burdened with conflict; following a violent outburst in 2001, the Ohrid Framework Agreement helped to establish a context for improved intergroup relations. For example, prior to the Orhid Agreement, Macedonian was the only official language and minorities were underrepresented in public administration. However, through decentralization, the agreement grants the right for a minority language to be a second official local language if that group comprises more than $25 \%$ in any municipality. The agreement also calls for greater representation of minorities in public administration, especially on a local level, to help balance the status and power among groups.

Although ethnic relations have improved, social distance remains in RNM. For example, the educational system perpetuates the parallel lives. Both Macedonians and Albanians use their right to education in their mother tongue; therefore, children attend separate schools or shifts. The educational system also lacks capacity to facilitate or promote better intergroup relations (Mickovska, Aleksova, \& Mickovska Raleva, 2011). As such, mutual stereotypes remain widespread among primary and secondary school students and staff (Petroska-Beska, 2012). By age 11, for example, children demonstrate interethnic prejudice and tensions, and show an understanding of group characteristics and symbols (Tomovska Misoska, 2014). This finding 
raises the question: when do children in this divided society demonstrate patterns of ethnic awareness?

This brief report presents a new, simple quantitative instrument that assesses patterns of children's ethnic awareness in RNM through categorization of symbols of everyday social and political life relevant to Macedonian and Albanian ethnic groups. This instrument aims to measure when children develop the first stage of SIDT, awareness of ethnic identity (i.e., Macedonian or Albanian). Findings are further examined by age and group status.

\section{Method}

\section{Procedures and Participants}

Two schools, with both Macedonian and Albanian language instruction, from municipalities with mixed ethnic composition were recruited because children in such settings tend to have more everyday contact with, and thus perhaps more awareness of, the 'other' group. Furthermore, choosing the municipalities with differences in the local majority may balance potential status differentials. The paper, however, refers to the national-level demographics: Macedonians as majority and Albanians as minority.

Principals consented for schools to participate; parental consent letters were sent home with children in grades 1 to 5 and children provided written assent. A total of 194 children participated $(\mathrm{M}=8.4, \mathrm{SD}=1.4$, range $6-11$ years old $57.7 \%$ female, $42.3 \%$ male $)$ with a balance of ethnic background (45.9\% Macedonian, 54.1\% Albanian). This sample size was selected because a priori power calculations suggested we needed 95 children in each group to detect a medium effect at $\alpha$ $=.01$ (Cohen, 1992). Children with both parents who did not identify with one of the two primary ethnic backgrounds were removed from current analyses $(n=3)$. Five participants were also removed due to experimenter error. 
Trained researchers worked with children one-on-one in a quiet area of the school. The tasks were administered on tablets via Qualtrics. Testing sessions lasted about 15 minutes, after which all children got a small prize and certificate of participation. Procedures were approved by the Ethics Committee at [Author-Identifying University].

\section{Materials}

The approach was adapted from earlier qualitative work with younger children in Northern Ireland (Connolly, Smith, \& Kelly, 2002). In the current study, children were randomly presented with 32 symbols (16 pairs: one from each ethnic background) which represented different aspects of everyday social and political life (Appendix 1). For example, as groups tend to live in different neighborhoods and use flags as visual markers of identity, awareness of these geographic areas and symbols was assessed. Given the importance of language, each alphabet was included. Symbols associated with religious traditions, as well as prominent historical figures (e.g., statues in prominent squares), along with symbols in children's everyday lives, such as sports and culture (e.g., celebrities), were measured.

The children were asked to drag and drop one of two paired symbols into a box randomly labelled either Macedonian or Albanian. If the symbol was categorized with the hypothesized ethnic label, it was coded 1 (e.g., RNM flag as 'Macedonian'); if categorized with the alternative ethnic label, it was coded 0 (e.g., RNM flag as 'Albanian'). All scores were then converted to the proportion of the symbols that children sorted with the hypothesized ethnic group. Higher scores indicated that children had a greater awareness of the category features associated with each ethnic background.

\section{Results}


A series of one sample t-tests was conducted to examine children's categorization against chance. The pattern of findings was examined by age and across majority (Macedonian) and minority (Albanian) participants. The significance level was adjusted using a Bonferroni correction $(p<.05 / 32$ symbols $=.0016)$ for each set of analyses.

First, the findings were examined by age (Table 1: columns 1 and 2). Participants were divided by the mean age of 8.4 years $(n=95(48.2 \%)<=8$ years; $n=102(51.8 \%)>8$ years $)$. For all ages, 27 of the 32 symbols were sorted into the hypothesized category. Five symbols were sorted into the hypothesized categories by older children, but not younger children (i.e., Macedonian street sign, Macedonian football jersey, both Macedonian and Albanian folk dancing, children wearing traditional Macedonian clothes). This set of findings suggest that even at early as six years old, children are aware of symbols that distinguish between these two ethnic groups in Macedonia. Moreover, age was positively correlated with ethnic awareness $(\mathrm{r}(187)=.274, p<$ $.001)$; that is, as children age, they become more aware of intergroup symbols. Further demonstrating the age patterns (Figure 1), 6-year-olds only sorted 8 of the 32 symbols above chance; by eight years old, two thirds are sorted with the hypothesized category, and by age ten, all of the symbols are sorted with the respective group.

Second, results were explored by children's ethnic background (Table 1: columns 3 and 4). Twenty-eight of 32 symbols sorted into the hypothesized category for children from both backgrounds. That is, regardless of whether it was an ingroup or outgroup symbol, children readily matched it to the hypothesized ethnic category (e.g., country flag, Vardar supporter logo, church as Macedonian; Albanian flag, Shkendija supporter logo, mosque as Albanian). One symbol did not sort above chance for participants from either background (traditional Macedonian folk dancing). The remaining three symbols only sorted into the hypothesized category for children 
from one background or the other. Two were sorted into the hypothesized category by outgroup participants only; specifically, Albanian participants sorted the Macedonian football jersey and the children wearing traditional Macedonian clothes as Macedonian, while the Macedonian participants did not. The final symbol only sorted above chance for ingroup members; Macedonian children categorized the Macedonian town square as Macedonian, while the Albanian participants did not. Across both majority and minority groups, primary school-aged children were aware of both ingroup and outgroup symbols.

\section{Discussion}

The current study used a simple, quantitative instrument to examine children's awareness of group symbols in a country with a recent outburst of violent ethnic conflict. By the age of six, both Macedonian (majority) and Albanian (minority) children were aware of symbols that serve as markers of the two ethnic groups. That is, children living in ethnically mixed municipalities, but attending separate classes in schools, were aware of symbols across different aspects of life such as sports, language, traditions, religion, cultural celebrities, and neighborhoods. The results were further statistically examined by age and majority/minority status, extending qualitative research in this area.

The results found that children build their repertoire of symbols of ethnic identity as they grow older, consistent with other post-accord settings (Connolly et al., 2002; Taylor, Dautel, \& Rylander, 2019). For example, older children were able to correctly sort the Macedonian traditional clothing, while the younger ones were not. Consistent with SIDT, this suggests that socializing contexts, such as schools, may have an accumulative effect on ethnic awareness. For example, both school curricula introduce concepts such as recognizing differences and respecting the tradition and culture of all people in third grade when the children are around eight years old. 
The instrument also captured some nuance in children's awareness of ethnic symbols. For example, in the capital, the main square is a common gathering place. In recent years, politicians have constructed a statue representing Macedonian identity in the square. This has been reflected in children's responses: only Macedonian children categorized the square as 'Macedonian,' while Albanian children did not. This may suggest that Macedonian children hear the rhetoric about the statue as a symbol of their ethnic identity, but Albanian children may still see the square as a public space that everybody uses. In contrast, both groups sorted the Skanderbeg square as Albanian. Moreover, Albanian children were better at recognizing the symbols of the other group related to traditions and everyday life, such as sports. This may reflect their status as a national minority group in which they are more attuned to the characteristics of the majority. For example, sporting events might be heightened times of tension between groups, as in other settings around the world, and football jerseys are visual markers of ethnic identity. Although both majority and minority children were aware of outgroup symbols, national group status may shape children's awareness of symbols in everyday life.

This study only included ethnically mixed municipalities; future research should test the instrument in areas with different ethnic compositions to see if awareness might vary based on exposure in everyday life. Despite this limitation, the results show the development of ethnic awareness, the first phase of SIDT, among 6-11 year-olds. The instrument could be used in future studies linking ethnic awareness to intergroup attitudes and behaviors in RNM or adapted to other conflict-affected societies. Examining the phases of SIDT may help to improve intergroup relations and promote peace, particularly among a generation born after the height of conflict (McKeown \& Taylor, 2017). 



\section{References}

Ajdukovic, D. \& Corkalo Biruski, D. (2008). Caught between the ethnic sides: Children growing up in a divided post-war community. International Journal of Behavioral Development, 34(4), 337-347. http://dx.doi.org/ 10.1177/0165025408090975.

Bar-Tal, D., Diamond, A.H. \& Nasie, M. (2017). Political socialization of children in intractable conflicts: Conception and evidence. International Journal of Behavioral Development, 41(3), 415-425. http://dx.doi.org/10.1177/0165025416652508.

Brewer, J.D. (1992). Sectarianism and racism, and their parallels and differences. Ethnic and Racial Studies, 15(3), pp. 352-364. https://doi.org/10.1080/01419870.1992.9993751.

Cohen, J. (1992). A Power Primer. Psychological Bulletin, 112(1), 155-159. doi.org/10.1037/00332909.112.1.155

Connolly, P., Smith, A., \& Kelly, B. (2002). Too young to notice? The cultural and political awareness of 3-6 year olds in Northern Ireland (p. 69, Rep.). NI Community Relations Council.

Cummings, E.M., Merrilees, C.E., Taylor, L.K., \& Mondi, C.F. (2017). Developmental and socialecological perspectives on children, political violence, and armed conflict. Development and Psychopathology, 29(1), 1-10. http://dx.doi.org/10.1017/S0954579416001061.

McKeown, S. \& Taylor, L.K. (2017). Intergroup contact and peacebuilding: Promoting youth civic engagement in Northern Ireland. Journal of Social and Political Psychology, 5(2), 415-434. doi: $10.5964 /$ jspp.v5i2.769

Mickovska, G., Aleksova, A., \& Mickovska Raleva, A. (2011). Strengthening of Multiethnic Cooperation in Municipalities Project: Report of the Baseline Study. Skopje: Macedonian Civic Education Center. 
Nesdale, D., Durkin, K., Maass, A., \& Griffiths, J. (2004). Group status, outgroup ethnicity and children's ethnic attitudes. Applied Developmental Psychology, 25, 237-251. http://dx.doi.org/10.1016/j.appdev.2004.02.005.

Petroska-Beska, V. (2012). Baseline Research Regarding the Interethnic Integration in Education. Skopje: Center for Human Rights and Conflict Resolution. http://pmio.mk/wpcontent/uploads/2013/04/IIEP-BASELINE-STUDY ENG.pdf.

Taylor, L.K., Dautel, J., \& Rylander, R. (2019). Symbols and labels: Children's awareness of social categories in a divided society. Poster presented at the International Society of Political Psychology (ISPP), Lisbon, Portugal.

Teichman, Y. (2016). Stereotypes and prejudice in conflict: A developmental perspective.in K. Sharvit \& E. Halperin (eds.) A Social-Psychology Perspective on the Israeli-Palestinian Conflict. http://dx.doi.org/ 10.1007/978-3-319-24841-7_2.

Tomovska Misoska, A. (2014). Giving children space to express themselves: exploring children's views and perspectives of contact programmes in Northern Ireland and the Republic of Macedonia. Compare: A Journal of Comparative and International Education, 44(5), 778800, http://dx.doii.org/10.1080/03057925.2013.792665. 


\section{Appendix 1}

Thirty-two images in 16 pairs, one hypothesized to be from each ethnic background, representing the areas of neighborhood and flags, language and prominent historical figures, sports and celebrities, and tradition and religion.

\begin{tabular}{|c|c|}
\hline \multicolumn{2}{|c|}{ Neighborhood and Flags } \\
\hline $\begin{array}{l}\text { Macedonian Street (marking the } \\
\text { neighbourhood as Macedonian by using } \\
\text { flags) }\end{array}$ & $\begin{array}{l}\text { Albanian Street (marking the neighbourhood } \\
\text { as Albanian by using flags) }\end{array}$ \\
\hline $\begin{array}{l}\text { Macedonian Sign (dwelling with majority } \\
\text { Macedonian population) }\end{array}$ & $\begin{array}{l}\text { Albanian Sign (dwelling with majority } \\
\text { Albanian population) }\end{array}$ \\
\hline $\begin{array}{l}\text { Main Square (square with a statue of } \\
\text { prominent figure related to the history of } \\
\text { Macedonians) }\end{array}$ & $\begin{array}{l}\text { Square Skanderbeg (square with a statue of } \\
\text { prominent figure related to the history of } \\
\text { Albanians) }\end{array}$ \\
\hline $\begin{array}{l}\text { North Macedonia Flag (country flag) } \\
\text { (Macedonians in the country tend to } \\
\text { identify with the flag as their own) }\end{array}$ & $\begin{array}{l}\text { Albanian Flag (flag of the Republic of } \\
\text { Albania, Albanians in the country identify } \\
\text { with it as their ethnic flag) }\end{array}$ \\
\hline \multicolumn{2}{|c|}{ Language and prominent historical figures } \\
\hline Cyrillic (Macedonian) Alphabet & Latin (Albanian) Alphabet \\
\hline $\begin{array}{l}\text { Cyril and Methodius Statue (authors of the } \\
\text { first Slavic alphabet, important for } \\
\text { spreading literacy and Christianity among } \\
\text { Slavs, many schools, statues, etc. bear their } \\
\text { name) }\end{array}$ & $\begin{array}{l}\text { Naim Frasheri Statue (famous Albanian poet } \\
\text { and part of the national movement for } \\
\text { independence of Albania from Ottoman rule, } \\
\text { many schools, statues bear his name) }\end{array}$ \\
\hline \multicolumn{2}{|c|}{ Sports and Celebrities } \\
\hline $\begin{array}{l}\text { Macedonian Football Club Logo (football } \\
\text { club that is perceived to be Macedonian } \\
\text { due to its ownership) }\end{array}$ & $\begin{array}{l}\text { Albanian Football Club Logo (football club } \\
\text { that is perceived to be Albanian due to its } \\
\text { ownership) }\end{array}$ \\
\hline $\begin{array}{l}\text { Macedonian Football Supporter Logo }(\log o \\
\text { of the supporters of the club bearing }\end{array}$ & $\begin{array}{l}\text { Albanian Football Supporter Logo (logo of } \\
\text { the supporters of the club bearing reference }\end{array}$ \\
\hline
\end{tabular}




\begin{tabular}{|l|l|}
\hline $\begin{array}{l}\text { reference to a historical group fighting for } \\
\text { Macedonian independence from Ottomans) }\end{array}$ & $\begin{array}{l}\text { to a historical group fighting for the interests } \\
\text { of Albanians in the Balkans) }\end{array}$ \\
\hline $\begin{array}{l}\text { Pelister Football Jersey (jersey of a football } \\
\text { club that is perceived to be Macedonian } \\
\text { due to its ownership) }\end{array}$ & $\begin{array}{l}\text { Renova Football Jersey (jersey of a football } \\
\text { club that is perceived to be Albanians due to } \\
\text { its ownership) }\end{array}$ \\
\hline $\begin{array}{l}\text { Singer Daniel Kajmakoski (a popular } \\
\text { singer performing in Macedonian) }\end{array}$ & $\begin{array}{l}\text { Singer Adrian Ghaxa (a popular singer } \\
\text { performing in Albanian) }\end{array}$ \\
\hline $\begin{array}{l}\text { Singer Karolina Goceva (a popular singer } \\
\text { performing in Macedonian) }\end{array}$ & $\begin{array}{l}\text { Singer Adelina Tahiri (a popular singer } \\
\text { performing in Albanian) }\end{array}$ \\
\hline \multicolumn{1}{|c|}{ Tradition and Religion } \\
\hline $\begin{array}{l}\text { Eggs for Easter (part of Macedonians' } \\
\text { tradition relating to Orthodox Christianity) }\end{array}$ & Baklava for Bajram (part of Albanians' \\
tradition relating to Islam)
\end{tabular}


Table 1

Images Sorting Against Chance by Child Background (N=194)

\begin{tabular}{|c|c|c|c|c|}
\hline & \multicolumn{2}{|c|}{ By Age } & \multicolumn{2}{|c|}{ By Background } \\
\hline & $\begin{array}{c}\text { Younger } \\
(<8.4 \text { years old })\end{array}$ & $\begin{array}{c}\text { Older } \\
(>8.4 \text { years old })\end{array}$ & $\begin{array}{l}\text { Albanian } \\
\text { (minority) }\end{array}$ & $\begin{array}{l}\text { Macedonian } \\
\text { (majority) }\end{array}$ \\
\hline Street-Mace & $* *$ & $\mathrm{~N} / \mathrm{A}$ & $* *$ & $* *$ \\
\hline Street - Alb & $* *$ & $* *$ & $* *$ & $* *$ \\
\hline Sign - Mace & $p=.007$ & $* *$ & $* *$ & $* *$ \\
\hline Sign - Alb & $* *$ & $* *$ & $* *$ & $* *$ \\
\hline Food - Mace & $* *$ & N/A & $* *$ & $* *$ \\
\hline Food - Alb & $* *$ & $\mathrm{~N} / \mathrm{A}$ & $* *$ & $* *$ \\
\hline Football Club - Mace & $* *$ & $* *$ & $* *$ & $* *$ \\
\hline Football Club - Alb & $* *$ & $* *$ & $* *$ & $* *$ \\
\hline FSL - Mace & $* *$ & $\mathrm{~N} / \mathrm{A}$ & $* *$ & $* *$ \\
\hline FSL - Alb & $* *$ & $* *$ & $* *$ & $* *$ \\
\hline Jersey - Mace & $p=.025$ & $* *$ & $* *$ & $p=.021$ \\
\hline Jersey - Alb & $* *$ & $* *$ & $* *$ & $* *$ \\
\hline Man - Mace & $p=.001$ & $* *$ & $* *$ & $* *$ \\
\hline Man - Alb & $* *$ & $* *$ & $* *$ & $* *$ \\
\hline Dance - Mace & $p=.776$ & $* *$ & $p=.019$ & $p=.102$ \\
\hline Dance - Alb & $p=.002$ & $* *$ & $* *$ & $* *$ \\
\hline Pope & $* *$ & $* *$ & $* *$ & $* *$ \\
\hline Imam & $* *$ & $\mathrm{~N} / \mathrm{A}$ & $* *$ & $* *$ \\
\hline Woman-Mace & $p=.001$ & $* *$ & $* *$ & $* *$ \\
\hline Woman - Alb & $* *$ & $* *$ & $* *$ & $* *$ \\
\hline Church & $* *$ & $\mathrm{~N} / \mathrm{A}$ & $* *$ & $* *$ \\
\hline
\end{tabular}




\begin{tabular}{|c|c|c|c|c|}
\hline Mosque & $* *$ & $\mathrm{~N} / \mathrm{A}$ & $* *$ & $* *$ \\
\hline Statue - Mace & $p=.001$ & $* *$ & $* *$ & $* *$ \\
\hline Statue - Alb & $* *$ & $* *$ & $* *$ & $* *$ \\
\hline Children - Mace & $p=.268$ & $* *$ & $* *$ & $p=.036$ \\
\hline Children - Alb & $p=.001$ & $* *$ & $* *$ & $* *$ \\
\hline Flag-Mace & $\mathrm{N} / \mathrm{A}$ & $* *$ & $* *$ & $* *$ \\
\hline Flag - Alb & $* *$ & $\mathrm{~N} / \mathrm{A}$ & $* *$ & $* *$ \\
\hline Alphabet - Mace & $* *$ & $\mathrm{~N} / \mathrm{A}$ & $* *$ & $* *$ \\
\hline Alphabet - Alb & $* *$ & $* *$ & $* *$ & $* *$ \\
\hline Square - Mace & $* *$ & $* *$ & $p=.004$ & $* *$ \\
\hline Square - Alb & $* *$ & $* *$ & $* *$ & $* *$ \\
\hline
\end{tabular}

Note. ${ }^{* *}$ is at the Bonferroni-corrected $p<.0016 ; \mathrm{N} / \mathrm{A}=$ t-test could not be computed because standard deviation was 0 (100\% of participants sorted it correctly).

Light Grey = only ingroup sorted above chance, but outgroup did not (e.g., Macedonian children categorized the Macedonian town square as Macedonian, while the Albanian participants did not).

Dark Grey = only outgroup sorted above chance, but ingroup did not (e.g., Albanian participants sorted the Macedonian football jersey as Macedonian, while the Macedonian participants did not). 
Figure 1. For each age group in the sample $(\mathrm{N}=194)$, the bars represent the number of symbols - out of 32 - that children sorted above chance with the hypothesized ethnic group, using the Bonferroni-adjusted $p<.0016$.

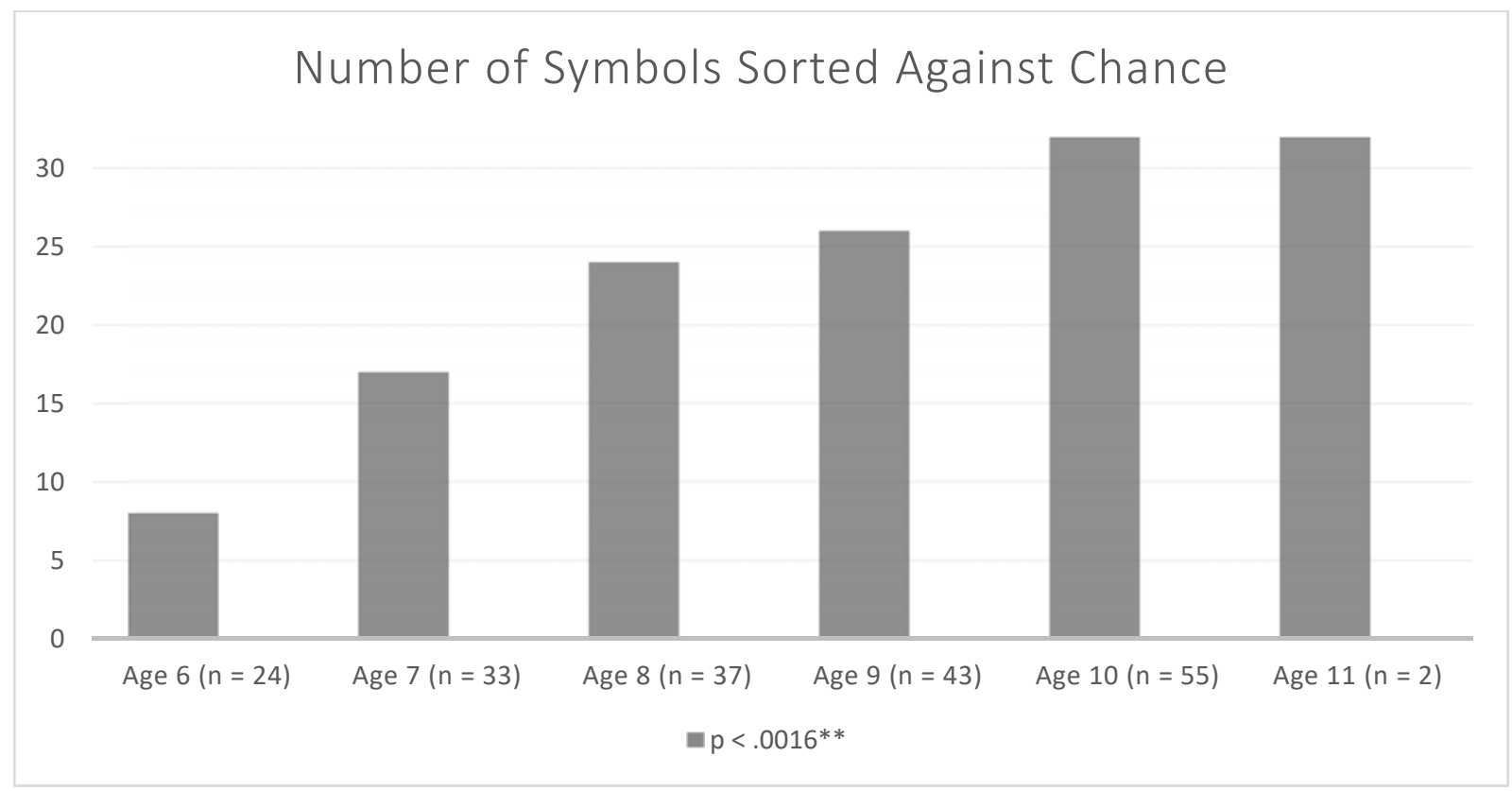

